\title{
An Investigation of the Depopulation in Northeastern Rural Regions of Japan Based on the Conjoint Analysis Modeling Approach
}

\author{
Megumi Nakagawa and Giido Izuta* \\ Department of Social Information Science \\ Yamagata Prefectural Yonezawa Women's Junior College \\ Yonezawa City, Yamagata Prefecture, 992-0025 Japan \\ *Corresponding author's email: Izuta [AT] yone.ac.jp
}

\begin{abstract}
The aim of this work was to get some insight into the social model relying on the voluntary human relocation-generated depopulation in northeastern (Tohoku region) rural towns of Japan under the assumption that urban areas (big cities) function as attractor-type entities on young people. In order to achieve this purpose, a study on the basis of the conjoint analysis (CA) survey was carried out at a junior college, in which the respondents were questioned about the relevant factors taken into account to decide where either to sojourn or to reside in after graduating college. As a matter of fact, the surveyees, whose ages ranged from 18 to 20 years old, were all female students enrolled in humanities courses. These 129 participants were all from towns and cities in Tohoku region with the huge majority of these localities being officially classified by the government as 'under-populated town', and yet none as 'big city'. As far as the experimental set up is concerned, the analysis focused on six CA attributes of big cities, namely, 'job', 'life', 'attraction (fascination)', 'entertainment and shopping', 'family reasons' and 'encounters', each provided with two CA levels. These attributes and levels were then translated into appropriate question-type sentences and carefully combined to make up five questionnaires, in which two of them were composed by three attributes whereas the others by two only. Either case, the respondents ranked the four conjoint cards on each questionnaire sheet according to their preferences and awareness. Then, the data processing was dealt with manually on a spreadsheet software application according to the standard choice-based CA procedure. It turned out that, whilst the importance value yielded the predominant attribute over the others within the questionnaire suggesting an evaluation order of the factors to establish the domicile of choice, the utility values are rather likely to express how the respondents felt towards their rural hometowns. Finally, regardless of the fact that this investigation was limited to a very particular sample population and confined to a specific territory, the results still help us not only shed some light on the addressed problem but also figure out some directions to make rural towns more attractive to young people.
\end{abstract}

Keywords--- Depopulation, human relocation, social model, conjoint analysis

\section{INTRODUCTION}

This paper is concerned with a social model that takes in variables as big cities, rural towns, and deliberate relocation of individuals from rural to urban areas at their entrance to the workforce as inputs, and comes up with some insight about the relationships between the depopulation phenomenon of the Japanese northeast countryside and the social perceptions -- including preferences -- of young people towards residential communities as its output. More specifically, the fundamental approach of this investigation is to endeavor to pave the way for unveiling the social elements that make a metropolis an attractor causing depopulation of surrounding rural areas by questioning from the human relocation perspective: 'what are the preference priorities like so that young people choose metropolis over rural towns?', and 'how metropolis and rural homelands come into their eyes one relatively to the other?'

To pursue this goal, a simple model consisting of six most common variables that were a priori singled out after many interview sessions performed during the preparatory phase of the research. These variables were paraphrased as questions to pull out the young people's preferences and awareness that rule their decisions on whether to live in rural hometowns or big cities after graduating higher education studies.

Apropos, it is worth noting that due to some technicalities as translation of words from Japanese into English, several jargons have slightly different meanings from those found in the standard literature. 
In fact, nevertheless the word 'depopulation' ('kaso' in Japanese) indeed refers to a decrease in population, there is a set of quantitative parameters that characterizes the depopulated condition of a local administration in the Japanese context (Takafumi, 2010; MIC, 2016a). It was first established in the 'Law concerning Emergency Measures for Underpopulated Areas' of 1970, and it has ever since been revised and updated every ten years to also reflect the effects of the declining in the birth rate and aging population concerns that the country as a whole has vis-a-vis. Under the law enacted in 2010 and in effect until 2020, the condition stated on the top of the definition list imposes a decrease of over $33 \%$ of population over a period of 45 years spanning from 1965 to 2010; and the number of rural towns and cities classified as 'depopulated' sum up to a little less than 800 as of 2016 (KASO-NET, 2016).

Likewise, care has to be taken when mentioning lingoes as city and town, which bear particular and somehow quantitative meanings. This is due to the Japanese 'Local autonomy law' that specifies different types of local authorities under the constitutional endorsement (CLAIR, 2010). As far as cities, towns and villages are concerned and focusing only on the minimum population size requisite as of 2016, they are classified into 'designated city' characterized by a population of over 500,000, 'core city' as well as 'special city' by over 200,000, 'ordinary city' by over 50,000 residents, and smaller administrative entities defined as 'town' and 'village' (MIC, 2016b). Despite this administrative division, laypersons roughly distinguish these types of cities in their daily lives, and should they do so, a city is conventionally alluded to as either 'city' or 'big city' only, in which the latter, although a matter of controversy, usually refers to one of the 20 'designated cities', or a 'core city' in the wide Tokyo metropolitan area, or a huge urban center as 'Tokyo'.

\section{LITERATURE REVIEW}

The depopulation phenomenon in Japanese rural regions is essentially characterized by aging population and human mobility from rural to urban areas with the former receiving a bit more attention than the latter in connection with the country's agenda to set forth counter measures. In this setting, Matanle (2014) makes extensive analyses of the demographic changes that Japan has undergone over the past years, future impacts on the domestic and global economies, and policies. Besides, on foreseeing similar pathways for neighboring Asian countries as Korea, China, and Thai, they examine how the Japanese experience can help these countries handle this challenge. In a somewhat different framework, Hewitt (2002) sounds the alarm on the potential labor force shortage that developed and industrialized countries in Europe and Japan are urged to think over. Then, they list a whole lot of policy topics and their pros and cons on assuming this hypothetical scenario.

In regard to human relocation as a cause of depopulation, Takeuchi (1974) discusses some of the determinant factors that motivate a massive translation of human resources from agricultural to metropolitan areas. They discussed the role of the development of agriculture and forestry in the ambit of depopulation phenomenon back in the 1970s. For an updated detailed description of the current issues see for example (Kato, 2014).

In a more recent but different geographic frame of reference, Nickel \& Day (1997) looked into the data of the local community and accomplished a time series analysis of its declining population, from which they concluded that environmental, demographic, geographical, and social economic factors are the attributes pulling the strings of human relocation.

Following the same lines of reasoning, recently, Jackson (2014) delved into a model with eight variables to lay out the mechanisms behind the depopulation due to aging, and discussed the results of extensive data analyses with regard to New-Zealand's growth.

Unlike the economic model approach adopted hitherto, this work targeted a social model based on the respondents' preferences towards their habitats. 


\section{METHODS}

The experimental procedure, respondent profile, conjoint cards, and data processing are described in this section.

Table 1: Sets of conjoint cards used in the experiment

\begin{tabular}{|c|c|c|c|c|}
\hline set 1 & $\begin{array}{l}\text { What do you think abeut } \\
\text { job and prefessienal } \\
\text { oppertunities? }\end{array}$ & $\begin{array}{l}\text { What do yeu think } \\
\text { aheet liviag and Hife } \\
\text { cenditioas? }\end{array}$ & $\begin{array}{l}\text { Do you feel any kind of } \\
\text { attraction fascination? }\end{array}$ & Rank \\
\hline Card I & bener chances in big cines & $\begin{array}{l}\text { better clicubere than in } \\
\text { neral howss }\end{array}$ & towands big cities & \\
\hline Card 2 & better chances in big crties & $\begin{array}{l}\text { nural sossa we as good } \\
\text { nelscubere }\end{array}$ & nural hometown -oricsted & \\
\hline Card 3 & $\begin{array}{l}\text { there are esouph in nual } \\
\text { towns }\end{array}$ & $\begin{array}{l}\text { beter clocslete thas in } \\
\text { nural tosess }\end{array}$ & nural femetown ariested & \\
\hline Card 4 & $\begin{array}{l}\text { there are enouph in naral } \\
\text { towns }\end{array}$ & $\begin{array}{l}\text { nural towas are as pood } \\
\text { as clicenhete }\end{array}$ & towards big cities & \\
\hline
\end{tabular}

\begin{tabular}{|c|c|c|c|}
\hline set 2 & $\begin{array}{l}\text { What do you think } \\
\text { about living and life } \\
\text { conditions? }\end{array}$ & $\begin{array}{l}\text { De you feel any kind of } \\
\text { attraction/fascination? }\end{array}$ & Rank \\
\hline Card 1 & $\begin{array}{l}\text { better elsewhere than in } \\
\text { rural towns }\end{array}$ & towands big cities & \\
\hline Card 2 & $\begin{array}{l}\text { better elsenhere than in } \\
\text { rural towns }\end{array}$ & nural hometowi -oriested & \\
\hline Card 3 & $\begin{array}{l}\text { runal towns are as good } \\
\text { as elsewhere }\end{array}$ & towants big cities & \\
\hline Card 4 & $\begin{array}{l}\text { runal towns ate as good } \\
\text { as elsewhere. }\end{array}$ & nural botsetown -oriented & \\
\hline
\end{tabular}

\begin{tabular}{|c|c|c|c|c|}
\hline set 3 & $\begin{array}{l}\text { What do you think } \\
\text { about entertainment and } \\
\text { shepping options? }\end{array}$ & $\begin{array}{l}\text { Do you have any family } \\
\text { reasens refrainiag you } \\
\text { fros moving out of } \\
\text { hometown? }\end{array}$ & $\begin{array}{l}\text { Where is likely to } \\
\text { meet your fricads } \\
\text { and or your match? }\end{array}$ & Rank \\
\hline Cand 1 & $\begin{array}{l}\text { either lick or ouly a few } \\
\text { places in naral home-town }\end{array}$ & it can be anywhere & in kig cities & \\
\hline Cand 2 & $\begin{array}{l}\text { eitier lack or only a few } \\
\text { places in nural houso-tons }\end{array}$ & $\begin{array}{l}\text { noving out of the } \\
\text { bametown is not an option }\end{array}$ & bonetomn & \\
\hline Cand 3 & not a big deal & it cas be anywhere & honetown & \\
\hline Cand 4 & not a big deal & $\begin{array}{l}\text { moviog out of the } \\
\text { botnetome is pot an option }\end{array}$ & in big cities & \\
\hline
\end{tabular}

\begin{tabular}{|c|c|c|c|}
\hline set 4 & $\begin{array}{l}\text { What do yos think about } \\
\text { living and life conditions? }\end{array}$ & $\begin{array}{l}\text { What do you think about } \\
\text { eatertainment and } \\
\text { shopping options? }\end{array}$ & Rank \\
\hline Card 1 & $\begin{array}{l}\text { better elsewhere tham in } \\
\text { rutal towns }\end{array}$ & $\begin{array}{l}\text { eitbet lack of only a few } \\
\text { places in rural home-town }\end{array}$ & \\
\hline Card 2 & $\begin{array}{l}\text { better elsewhere than in } \\
\text { rumal towns }\end{array}$ & not a big deal & \\
\hline Card 3 & $\begin{array}{l}\text { numal towns are as good an } \\
\text { elsenthere. }\end{array}$ & $\begin{array}{l}\text { cither lack or only a few } \\
\text { places in rural home-town }\end{array}$ & \\
\hline Card 4 & $\begin{array}{l}\text { rural tomm are us good an } \\
\text { thenhere }\end{array}$ & not a big deal & \\
\hline
\end{tabular}

\begin{tabular}{|l|l|l|l|}
\hline set $\mathbf{5}$ & $\begin{array}{l}\text { What do you think about } \\
\text { entertainment and } \\
\text { shopping options? }\end{array}$ & $\begin{array}{l}\text { Do you feel any kind of } \\
\text { attraction/fascination? }\end{array}$ & Rank \\
\hline Card 1 & $\begin{array}{l}\text { cither lack or only a few } \\
\text { places in nural hometown }\end{array}$ & towards big cities & pack \\
\hline Card 2 & $\begin{array}{l}\text { either lack or only a few } \\
\text { places in niral hometown }\end{array}$ & rural hometown -oriented & \\
\hline Card 3 & not a big deal & towards big cities & \\
\hline Card 4 & not a big deal & nural hometown -oriented & \\
\hline
\end{tabular}




\subsection{Experiment}

The experiment consisted of a survey carried out in a Japanese junior college located in the northeastern region of Japan (also called Tohoku region) in order to investigate the main reasons that keep students from going back to their hometowns after graduation, which in turn bring eventually about the depopulation problem that many rural towns/cities in this zone are struggling to put a break on. The survey is essentially a conjoint analysis designed to bring out those preference-related feelings that the respondents have towards either big cities (metropolis) or their countryside hometowns as these two contrasting urban areas are compared against each other for the conjoint attributes defined in the next subsection.

\subsection{Conjoint Cards}

Here, 5 sets of 4 conjoint cards each were used in the study as shown in Table 1 . The respondents were asked to rank the cards with numbers from 1 through 4 for each set, where number 1 indicates the combination on the card that best reflects surveyee's preference whereas number 4 the least. The basic assumption of situational approach was stated as 'Imagine the main reasons for your choosing a metropolis over rural town or vice versa after graduating college; then rank the cards according to your agreement/concordance level'. Under these circumstances, the attributes and levels of this conjoint analysis expressed in Table 1 as questions with possible answers are as follows: (a) attribute 'job' with levels 'in big cities' and 'enough in rural towns', (b) attribute 'life' with levels 'big cities' and 'rural is also ok', (c) attribute 'attraction' with levels 'towards big cities' and 'rural hometown oriented', (d) attribute 'entertainment and shopping' with levels 'not enough in rural towns' and 'not a big deal', (e) attribute 'family reasons' with levels 'moving out is ok' and 'moving out is not ok', (f) attribute 'encounters' with levels 'in big cities' and 'hometown'.

\subsection{Data Processing}

The spreadsheet application 'Excel 2013' running on a computer powered with the operating system 'Windows 8.1' was used to tab and process the data read out of the conjoint cards for each set. The choice-based conjoint analysis was manually performed according to the standard procedures described in data processing related literature (Kan, 2007). In this work, the value of 0.8 for 'precision of measurement' $\left(\mathrm{R}^{2}\right.$ index) was adopted as the rule of thumb for accepting the analysis results. Thus, for each set, the cards of same rank order were gathered and then these groups were combined and processed together as long as the precision of measurement met the standard. The respondents were classified and characterized making sure that the chunks of data were combined only once.

\subsection{Respondents}

The respondents were all Japanese female students of a junior college for women. The college with courses only in humanities is located in a city in the northeast region of Japan far about 3 hours by bullet train from Tokyo and with a population of approximately 88,000. The 129 students were all between 19 and 21 years old and their hometowns were somewhere in the Tohoku region; and the majority of these towns were small-scale cities with a population of around 100,000 . None of the students were from cities with a population exceeding 1,000,000, which in Japan is considered a relatively big city or a regional center.

\subsection{Scope and Limitations of Study}

The scope of this study was limited to young female students and Tohoku region, and the survey was carried out in the year 2016. Moreover, since Tohoku is unique in the sense that this region has long lasting winter with heavy snow, the results may neither be able to be generalized outside the region nor reflect a general tendency of young people. 


\section{RESULTS}

5. In this section, the results of conjoint analyses, which are given as graphs of utility values (also known as partworth), importance and clustering of respondents.

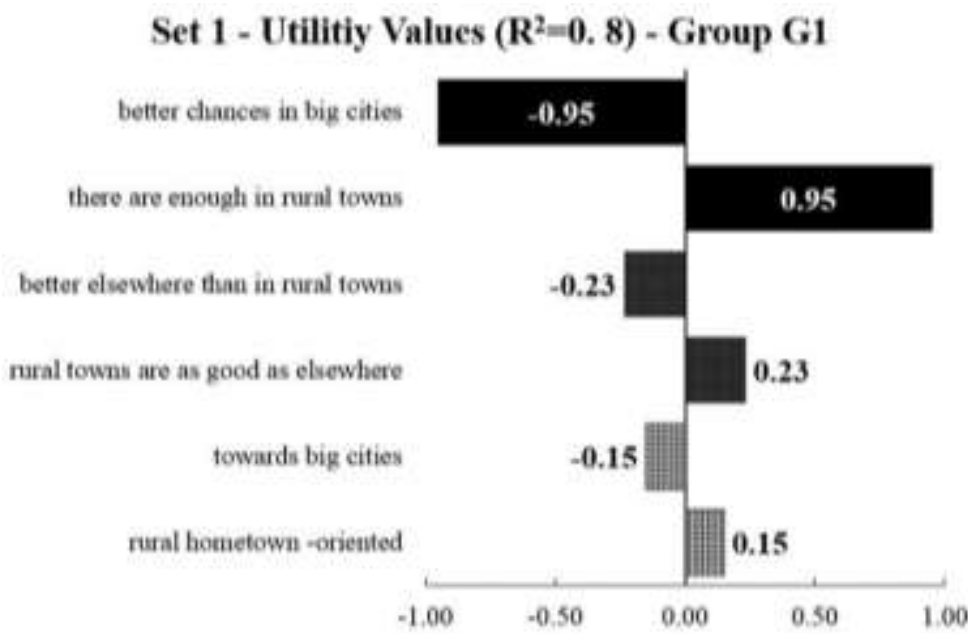

Set 1 - Importance Values $\left(R^{2}=0.8\right)$ - Group $G 1$

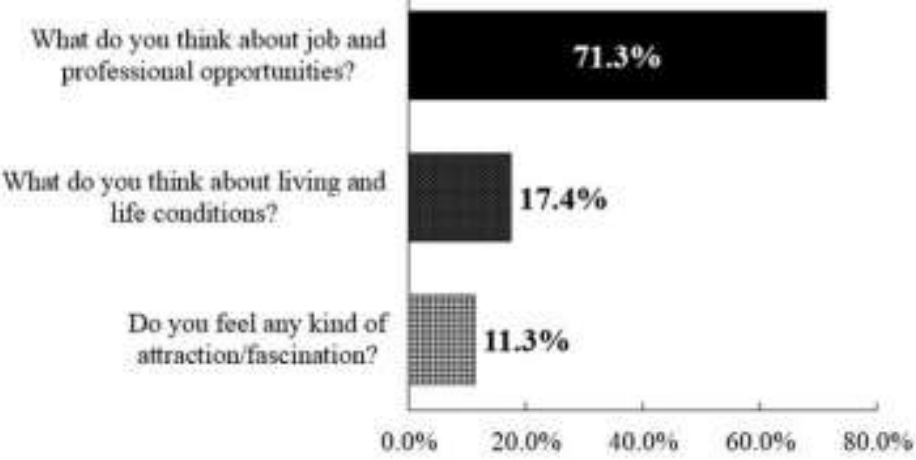

Fig. 1: Utility and importance values for the largest group made out of set 1

Table 2: Groups drawn out of set 1

\section{Set 1 - Classification based on the Conjoint Analysis}

\begin{tabular}{|c|c|c|l|l|}
\hline Group & $\%$ & $\mathbf{R}^{2}$ & $\begin{array}{c}\text { Attribute (from } \\
\text { Importance } \\
\text { Parameter) }\end{array}$ & $\begin{array}{c}\text { Level (from Utility } \\
\text { values) }\end{array}$ \\
\hline G1 & 56.6 & 0.8 & job & enough in rural towns \\
\hline G2 & 21.7 & 0.9 & attraction & rural town oriented \\
\hline G3 & 8.5 & 0.8 & job & in big cities \\
\hline G4 & 6.2 & 0.9 & attraction & towards big cities \\
\hline G5 & 3.1 & 1.0 & life & nural is also ok \\
\hline G6 & 3.9 & 0.8 & life & big cities \\
\hline
\end{tabular}




\subsection{Analysis of Set 1}

The rank cards given in the uppermost part of Table 1 led to utility and importance values for the group with the greatest number of respondents as displayed in Fig. 1. From the importance graph, it is clear that the question "what do you think about job and professional opportunities?' (attribute 'job') accounted for 71.3\%, and 'what do you think about living and life conditions?' (attribute 'life') came second with $17.4 \%$. Now, utility graph says that the level 'enough in rural towns' expressed by the answer 'there are enough in rural towns' characterizes the group in the sense that the individuals in this group consider the attribute 'job' as the main factor when compared with attributes 'life' and 'attraction' as the most dominant factor in deciding whether or not to return to rural hometowns, but as far as their current own situations are concerned, they don't feel that 'job' opportunities are an issue in their hometowns. As a matter of fact, this group G1 is comprised of $56.6 \%$ of the total number of respondents and the precision of measurement $\left(\mathrm{R}^{2}\right)$ of the conjoint analysis was 0.8 as described in Table 2 along with other groups singled out from the data set. Indeed, the second largest group added up to $21.7 \%$ with the decisive factor being the attribute 'attraction', even though in their particular case the prevailing attribute level was 'rural town oriented'. Interestingly the number of those who considered the attribute 'job' and its level 'in big cities' summed up only to $8.5 \%$ of the respondents 


\section{Set 2 - Utilitiy Values $\left(R^{2}=0.8\right)$ - Group $G 1$}

better elsewhere than in rural towns

rural towns are as good as elsewhere

\section{$-0.87$}

towards big cities

$-\mathbf{0 . 5 0}$

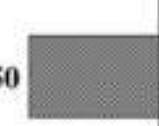

rural hometown -oriented

0.50

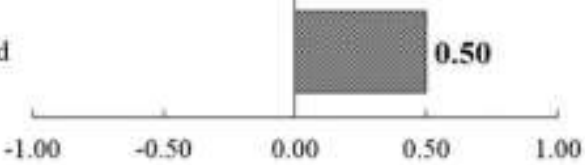

Set 2 - Importance Values $\left(R^{2}=0.8\right)$ - Group $G 1$

What do you think about living and life conditions?

\section{$59.0 \%$}

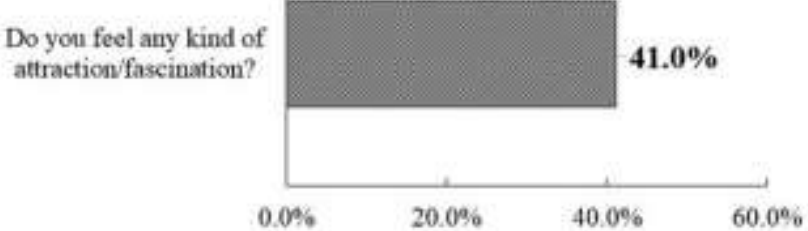

Fig. 2: Utility and importance values for the largest group made out of set 2

Table 3: Groups drawn out of set 2

Set 2 - Classification based on the Conjoint Analysis

\begin{tabular}{|c|c|c|l|l|}
\hline Group & $\%$ & $\mathbf{R}^{2}$ & $\begin{array}{c}\text { Attribute (from } \\
\text { Importance } \\
\text { Parameter) }\end{array}$ & $\begin{array}{c}\text { Level (from Utility } \\
\text { values) }\end{array}$ \\
\hline G1 & 69.0 & 0.8 & life & big cities \\
\hline G2 & 11.6 & 0.9 & life & big cities \\
\hline G3 & 6.2 & 0.8 & life & rural is also ok \\
\hline G4 & 8.5 & 0.9 & attraction & rural hometown oriented \\
\hline other & 4.7 & low & & \\
\hline
\end{tabular}




\subsection{Analysis of Set 2}

Set 2 is a simplified version of set 1 with attribute 'job' ruled out. Thus, it assesses the surveyees' preferences between attributes 'life' and 'attraction' only. As shown in Fig.2, the largest group is characterized by answering 'better elsewhere than in rural towns' to the question 'what do you thing about living and life conditions?' as the outweighing aspect inducing depopulation in rural areas. In fact, this group is constituted by $69.0 \%$ of the respondents as represented in Table 3, which has in it the group G2 with the same features as group G1. Notwithstanding these groups refer to the same conceptual characterization, they are tabbed separately simply due to different data processing steps from which they were produced. Thus merging both groups down into a single category, they make up $81.6 \%$ of the data set. This figure suggests that the students composing the group would choose to live in a place where they could get better living and life conditions than in rural towns. The group 'other' stands for the set of respondents not only unrelated to other groups but also among themselves in the sense that the precision of measurement fell short of the minimum value established as the standard in this study. 


\section{Set 3 - Utilitiy Values $\left(R^{2}=0.8\right)$ - Group $G 1$}
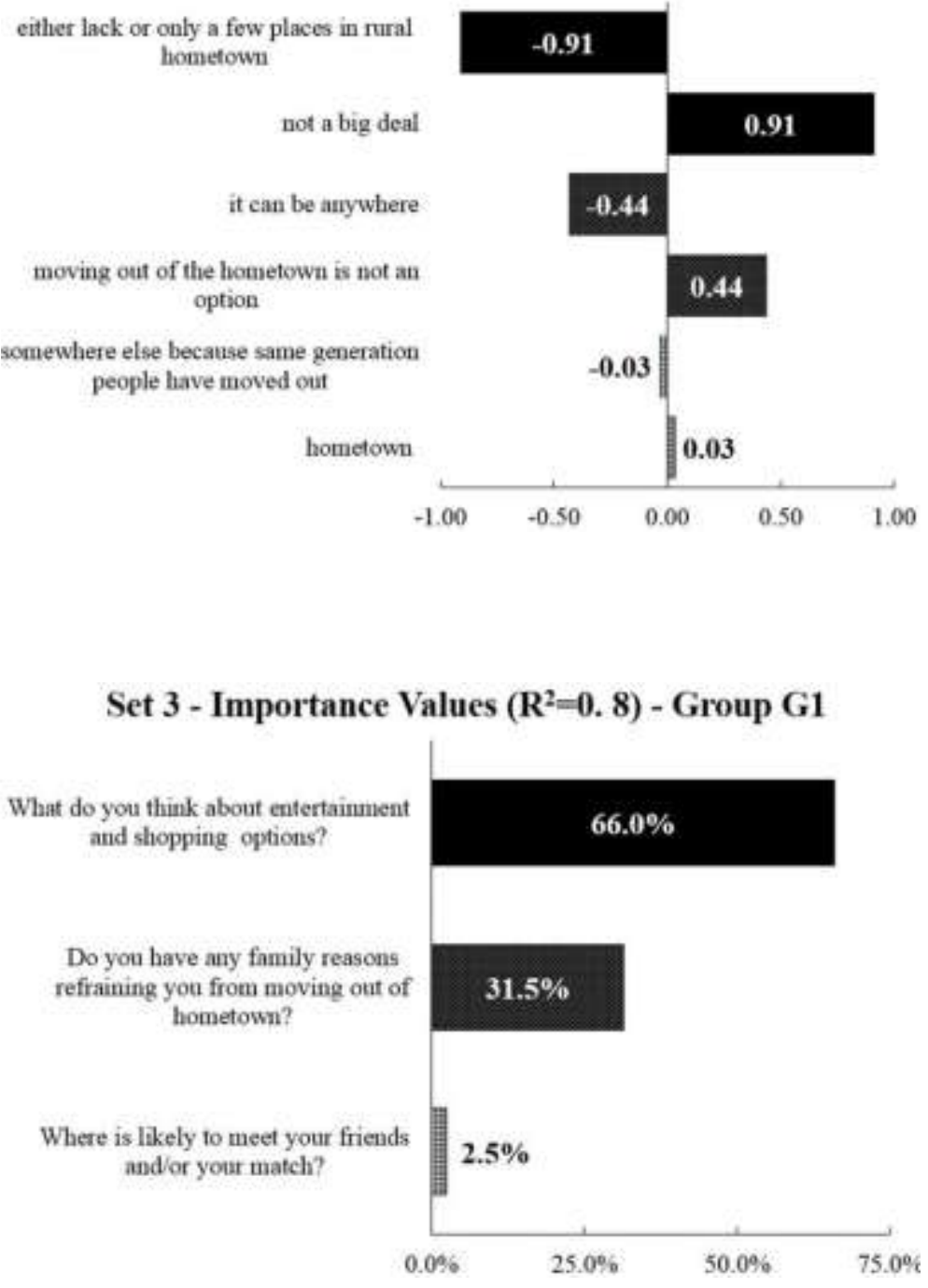

Fig. 3: Utility and importance values for the largest group made out of set 3

Table 4: Groups drawn out of set 3

Set 3 - Classification based on the Conjoint Analysis

\begin{tabular}{|c|c|c|c|l|}
\hline Group & $\%$ & $\mathbf{R}^{2}$ & $\begin{array}{c}\text { Attribute (from } \\
\text { Importance } \\
\text { Parameter) }\end{array}$ & $\begin{array}{c}\text { Level (from Utility } \\
\text { values) }\end{array}$ \\
\hline G1 & 67.4 & 0.8 & $\begin{array}{c}\text { entertainment } \\
\text { and shopping }\end{array}$ & not a big deal \\
\hline G2 & 10.9 & 0.8 & family reasons & moving out is ok \\
\hline G3 & 7.8 & 0.9 & encounters & hometown \\
\hline G4 & 6.2 & 0.8 & encounters & in big cities \\
\hline other & 7.8 & low & & \\
\hline
\end{tabular}




\subsection{Analysis of Set 3}

As shown in Fig. 3, set 3 is made of three questions that correspond to attributes defined as 'entertainment and shopping, 'family reasons', and 'encounters'. Among them, 'what do you think about entertainment and shopping options?" had the highest importance value with 'not a big deal' being its representative level. In fact, this group, labelled G1 in Table 4, covered $67.4 \%$ of the respondents meaning that more than half of the students feel this attribute being crucial to do an about-face to rural towns, even though it is not their case currently. On the other hand, group G2 accounting for $10.9 \%$ is featured by the question 'Do you have any family reasons refraining you from moving out of hometown?' and the answer 'it can be anywhere else', which imply that the corresponding attribute is relatively very compelling to determine where to settle down after graduating higher education. Furthermore, groups G3 and G4 focused on 'where is likely to meet your friends and your match?' with antagonistic levels. 


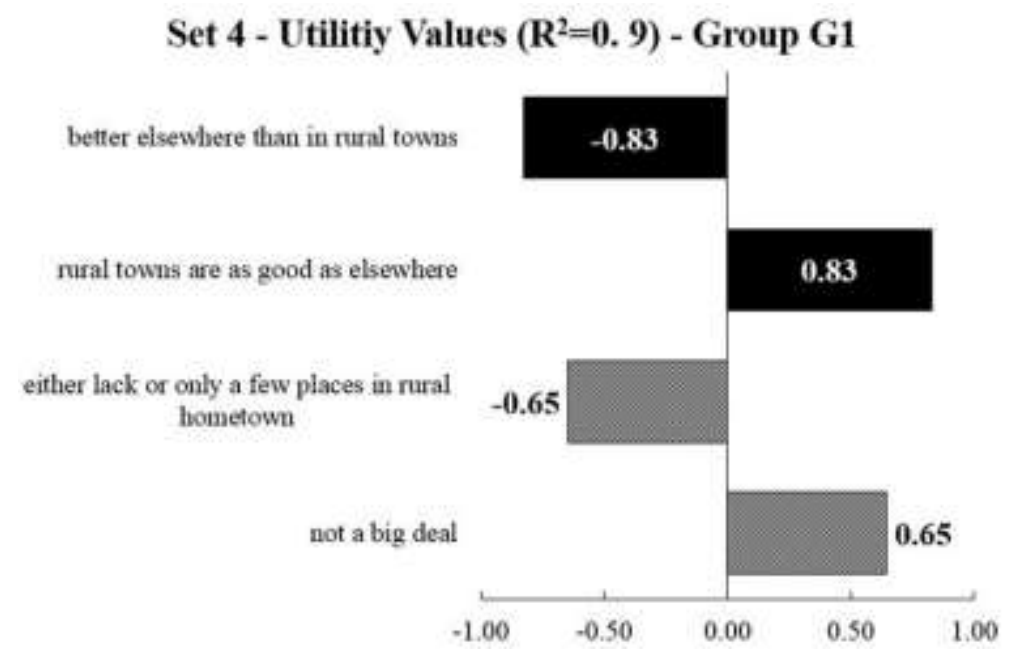

Set 4 - Importance Values $\left(R^{2}=0.9\right)$ - Group G1

What do you think about living and life conditions?

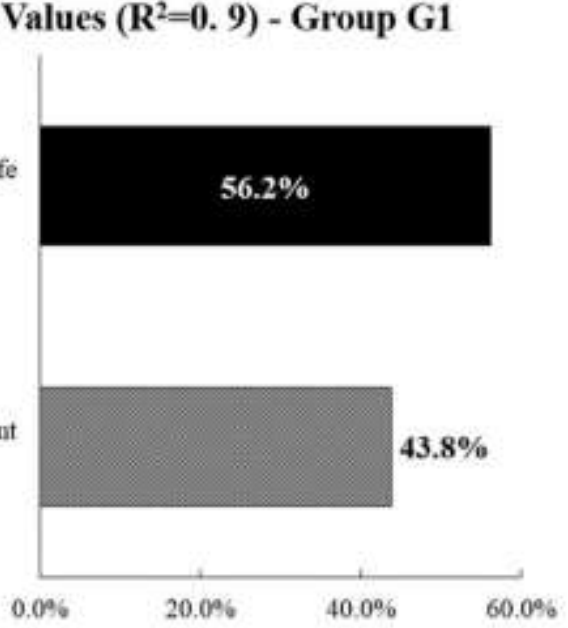

What do you think about entertainment and shopping options?

Fig. 4: Utility and importance values for the largest group made out of set 4

Table 5: Groups drawn out of set 4

\section{Set 4 - Classification based on the Conjoint Analysis}

\begin{tabular}{|c|c|c|l|l|}
\hline Group & $\%$ & $\mathbf{R}^{2}$ & $\begin{array}{c}\text { Attribute (from } \\
\text { Importance } \\
\text { Parameter) }\end{array}$ & $\begin{array}{c}\text { Level (from Utility } \\
\text { values) }\end{array}$ \\
\hline G1 & 72.1 & 0.9 & life & rural town is ok \\
\hline G2 & 13.2 & 0.8 & life & big cities \\
\hline G3 & 7.0 & 0.8 & $\begin{array}{l}\text { entertaiment } \\
\text { and shopping }\end{array}$ & not a big deal \\
\hline other & 4.7 & low & & \\
\hline
\end{tabular}




\subsection{Analysis of Set 4}

Fig. 4 shows that the attribute 'life' was predominant when the questions 'what do you think about living and life conditions' and 'what do you think about entertainment and shopping options' were benchmarked against each other, and the results of the grouping procedure are depicted in Table 5, in which the conspicuous point comes down to the fact that whilst group G1 with $72.1 \%$ chose level 'rural town is ok', G2 with $13.2 \%$ preferred 'big cities'. All in all, these results tip off that the participants would favor living conditions, which include among other things, factors as transportation, access to information, climate and leisure, over entertainment if they were ever to find out on their own where to live. It is worth noting that group G2 voted for the level 'big cities', which hints to the possibility that these respondents feel already somehow not fulfilled with what rural towns have to offer. 


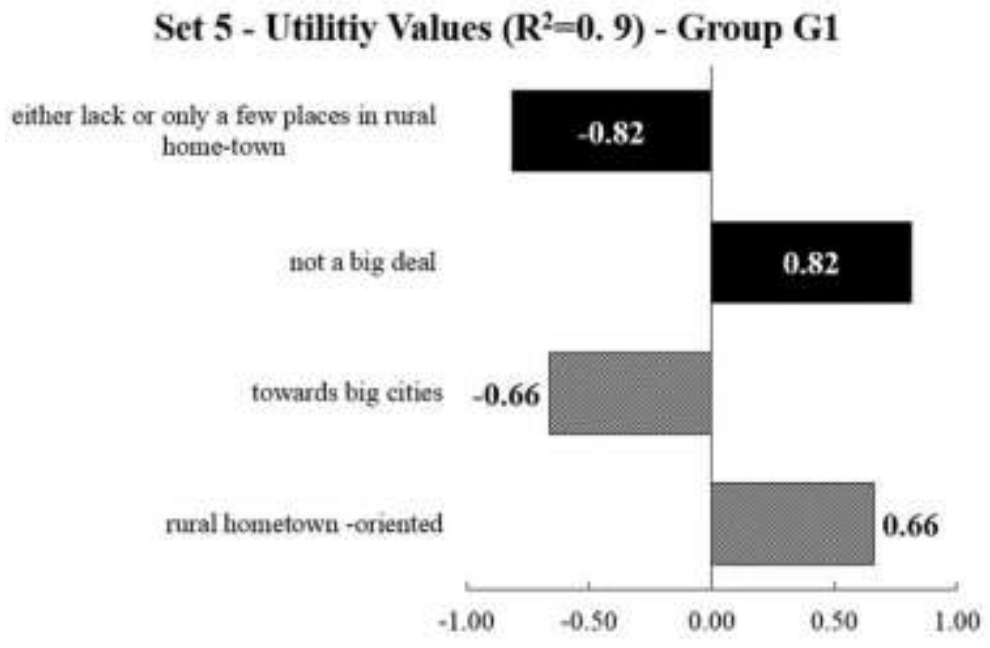

Set 5 - Importance Values $\left(R^{2}=0.9\right)$ - Group $G 1$

What do you think about entertaimment and shopping options?

$55.2 \%$

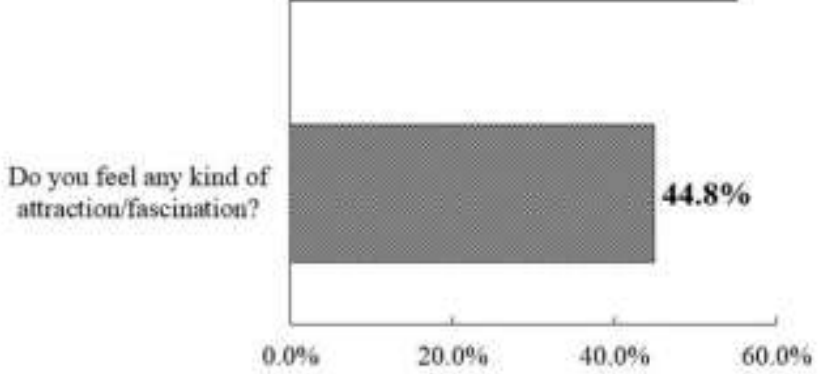

Fig. 5: Utility and importance values for the largest group made out of set 5

Table 6: Groups drawn out of set 5

\section{Set 5 - Classification based on the Conjoint Analysis}

\begin{tabular}{|c|c|c|c|c|}
\hline Group & $\%$ & $\mathbf{R}^{2}$ & $\begin{array}{c}\text { Attribute (from } \\
\text { Importance } \\
\text { Parameter) }\end{array}$ & $\begin{array}{c}\text { Level (from Utility } \\
\text { values) }\end{array}$ \\
\hline G1 & 85.3 & 0.9 & $\begin{array}{c}\text { entertaiment } \\
\text { and shopping }\end{array}$ & not a big deal \\
\hline G2 & 4.7 & 0.8 & attraction & towards big cities \\
\hline G3 & 4.7 & 0.8 & $\begin{array}{c}\text { entertaiment } \\
\text { and shopping }\end{array}$ & not enough in rural towns \\
\hline other & 5.4 & low & & \\
\hline
\end{tabular}




\subsection{Analysis of Set 5}

Comparison of attribute 'entertainment and shopping' with 'attraction' begets the importance and utility plots illustrated in Fig. 5, which mean that 'what do you think about entertainment and shopping?' is of paramount concern in this questionnaire; however, it is not a big deal presently. In referring to Table 6, these answers formed group G1 with $85.3 \%$ of students against the $4.7 \%$ of group G3 that supported the level 'not enough in rural towns'. Finally, G2 sustained big cities in regard to the attribute 'attraction'.

\section{DISCUSSION}

Comparisons of attributes 'job', 'life' and 'attraction' coped with sets 1 and 2 (Table 2, 3) propound an order of priority among them for making the decision on which environs, whether rural or urban, would suit best their requirements and future life styles. In fact, the analyses rendered a list with 'job' atop and 'attraction' on the nether part. In addition, the collaborators felt that their rural towns offered rather enough options to fulfill their requisites as pointed out by the levels. These results are reasonable if we recall that the students were all in humanities courses and, without any intention of stereotyping, they pursue in general professional careers in service sectors and public service. Hence, it is fair to surmise that young people pursuing careers as in high tech, scientific and others requiring high specialty fields would presumably have different feelings towards rural towns unless these were part of a high techno-polis, or provisioned with specialized research and development facilities or parks of sorts; and, as a consequence, not reaching to a consensus that would allow us to form groups on the grounds of the conjoint analysis.

Now, weighing the attributes 'entertainment and shopping', 'family reasons' and 'encounters', the outcomes pointed to the preponderance of the former (Table 4), which showed to be so over the attribute 'attraction'. Nonetheless, it fell behind when benchmarked against the attribute 'life' (Table 5).

On the whole, the proposed model here clues us in on the existence of a priority order in which the respondents consider to make their decisions; i.e., starting with 'job' then 'life', followed by 'entertainment and shopping', and finally either 'family reasons' or 'encounters'. This finding in light of the work of Nickels \& Day (1997) imply that 'job' standing for economic factors comes first whereas the last three attributes associated with social factors last. Yet, the attribute 'life' depends on the aspect spotted. For example, in Tohoku region it could be the winter weather influencing on their life styles, in which case it would correspond to environmental factors in the sense of the previously cited report.

Finally, the results of this work contributes to the study of the relationships between depopulation and young people, which in turn help understand what young generations are expecting from their environment in order to feel better off.

\subsection{Acknowledgement}

The authors would like to thank the students for the cooperation. Thanks also go to the staff members, colleagues and friends for the support and cooperation. Finally, the authors are grateful to their institution for the supporting funds.

\section{REFERENCES}

- CLAIR. (2010). Local Government in Japan. Council of Local Authorities for International Relations. http://www.jlgc.org.uk/en/pdfs/LocalGovernmentInJapan2010.pdf

- Hewitt, P. S. (2002). Depopulation and Ageing in Europe and Japan: The Hazardous Transition to a Labor Shortage Economy. Internationale Politik und Gesellschaft (Bonn), 1, 111-20.

- Jackson, N. (2014). Sub-National Depopulation in Search of a Theory -Towards a Diagnostic Framework. New Zealand Population Review, 40, 3-39.

- $\quad$ Kan, T. (2007). Learning Multivariate Analysis with Excel. Ohm Publ. Tokyo (in Japanese).

- KASO-NET. (2016). About Depopulation. Federation for Promotion of Self-Sustainability of Under-populated Areas. Retrieved 2016/7 from http://www.kaso-net.or.jp

- Kato, H. (2014). Declining Population and the Revitalization of Local Regions in Japan. Meiji Journal of Political Science and Economic, 3, 25-35. 
- Matanle, P. (2014). Ageing and Depopulation in Japan Understanding the Consequences for East and Southeast Asia in the 21st Century. In H. Dobson (ed.) East Asia in 2013: A Region in Transition, White Rose East Asia Centre and Foreign and Commonwealth Office Briefing Papers. Sheffield: WREAC. 30-35.

- $\quad$ MIC. (2016a). Acts to Promote Self-Sustainability of Under-populated Areas. Ministry of Internal Affairs and Communications. Retrieve 2016/7 from http://www.soumu.go.jp/

- main_sosiki/jichi_gyousei/c-gyousei/2001/kaso/kasomain1.htm

- $\quad$ MIC. (2016b). Local Autonomy Law. Ministry of Internal Affairs and Communications. Retrieved 2016/7 from http://www.soumu.go.jp/main_sosiki/jichi_gyousei/bunken/

- chihou-koukyoudantai_kubun.html

- Nickels, C. R., \& Day, F. A. (1997). Depopulation of the Rural Great Plains Counties of Texas. Great Plains Research 7, (Fall 1997), 225-250.

- http://digitalcommons.unl.edu/greatplainsresearch

- Takami, F. (2010). Current Status and Issues of Anti-Under Population Acts - Towards a New Act. House of Councilors - The National Diet of Japan - Rippo to Chosa, 300, 16-29. http://www.sangiin.go.jp/japanese/annai/chousa/rippou_chousa/backnumber/

- Takeuchi, K. (1974). The Rural Exodus in Japan (1) -Basic Consideration for International Comparison. Hitotsubashi Journal of Social Studies, 7(1). 17-38 